\section{Comparison of Field Resistance to Phytophthora cinnamomi in Twelve Avocado Rootstock}

\author{
B.K. Gabor, F.B. Guillemet, and M.D. Coffey \\ Department of Plant Pathology, University of California, Riverside, \\ CA 92521
}

Additional index words. Persea americana, Phytophthora root rot

\begin{abstract}
Twelve avocado (Persea americana Mill.) rootstock selections were tip-grafted with a commercial scion, CV. Hass, and evaluated for their field resistance to Phytophthora cinnamomi Rands. Percentage difference in trunk cross-sectional area of the inoculated compared to uninoculated rootstock, the overall growth in trunk crosssectional area, and visual rating of disease severity of the commercial scion were used to evaluate rootstock over 79 weeks. Avocado trees on the rootstock selections Thomas, Martin Grande (G75Sa, b, and c), Barr Duke, and D9 demonstrated the highest level of resistance to $P$. cinnamomi, whereas those on Topa Topa, Borchard, and G6 had the lowest levels. Trees on Duke 7, G1033, and Toro Canyon rootstock were intermediate in their levels of resistance. Among uninoculated rootstock, trees on Thomas and G6 exhibited the greatest growth in trunk cross-sectional area. whereas those on D9 showed the least.
\end{abstract}

Phytophthora root rot (PRR), caused by Phytophthora cinnamomi, is the principal disease problem of avocados in many areas of the world (Coffey, 1987; Kotzé and Darvas, 1983; Pegg et al., 1982). P. cinnamomi was first identified as the causal agent of PRR on avocados in California in 1942 (Wager, 1942). It now affects $\approx 60 \%$ to $75 \%$ of the groves in the state. In 1987, annual losses from PRR in California were estimated to be about $\$ 30$ million (Coffey, 1987).

An important feature of the integrated approach for control of PRR is the use of vegetatively propagated clonal rootstock that express moderate resistance to $P$. cinnamomi (Coffey, 1987; Zentmyer, 1980). The identification of moderate resistance in seedlings of the Duke cultivar in the 1950s (Zentmyer, 1963) gave rise to an extensive collecting and screening program of the avocado and other closely related Persea sp. from Central America, Mexico, and California (Zentmyer, 1978). Selections that have shown moderate resistance to PRR include Duke 7 and G6 (Zentmyer, 1978).

Recently, the three Martin Grande selections (G755 a, b, c) from Guatemala have exhibited resistance (Coffey, 1987; Coffey and Guillemet, 1987). Other new selections, such as Thomas, also have given good indications of useful resistance in preliminary tests (Coffey, 1987).

The ultimate test of resistance in a rootstock is to evaluate it in the field, grafted with a commercial scion, in the presence of

Received for publication 19 Jan. 1990. This project was funded by a grant from the California Avocado Commission. We thank Steve Campbell and Greg Greer for their excellent technical assistance and BettyAnn Merrill for typing the manuscript. The cost of publishing this paper was defrayed in part by the payment of page charges. Under postal regulations, this paper therefore must be hereby marked advertisement solely to indicate this fact. the pathogen. This paper reports on the field performance of avocado trees on 12 rootstock either uninoculated or inoculated with $P$. cinnamomi.

Twenty each of 12 rootstock (Table 1) were propagated as cuttings (Dolan and Coffey, 1986; Frolich and Platt, 1971). The rootstock were rooted in a mix of 1 peat : 1 peflite $(\mathrm{v} / \mathrm{v})$, transferred into 10 -liter pots, and allowed to develop an extensive root system. Rootstock were tip-grafted with the commercial scion, CV. Hass, 12 months before being planted in the field. The experiment was conducted at the South Coast Field Station near Tustin, Calif., on a San Emigdio sandy loam soil (coarse-loamy, mixed calcareous, thermic Typic Xerofluvents) (Wachtell, 1978) (67\% sand, 18\% silt, 15\% clay, $\mathrm{pH}$ 7). Each tree was planted in a 30 cm-diameter hole, $45 \mathrm{~cm}$ deep, spaced 4.6 $\mathrm{m}$ within a row and $6 \mathrm{~m}$ between rows in a completely randomized design. Trees were irrigated with minisprinklers twice a week.

Ten randomly selected trees on each rootstock were inoculated with $P$. cinnamomi 4 weeks after planting. The inoculum consisted of $P$. cinnamomi grown on sterilized millet seed for 1 week and then mixed with UC mix C (Baker, 1972) to a final concentration of 30 propagules/g soil dry weight (ppg). The inoculum was placed in two $4 \times$ $15-\mathrm{cm}$ (diameter/depth) holes, positioned opposite each other immediately adjacent to the root ball, which was then covered with a $2.5-\mathrm{cm}$ casing of field soil.

The remaining 10 trees of each selection were used as uninoculated controls. To prevent infection of these trees, each tree was treated with a solution containing the fungicide fosetyl-Al at $3 \mathrm{mg} \cdot \mathrm{ml}^{-1}$, initially applied as a 1-liter preplant drench, then as foliar sprays to runoff at monthly intervals for the first 6 months and every 3 months thereafter. A reference point on the trunk of each rootstock was marked with paint and used for diameter measurements. The trunk cross-sectional area (TCSA) was calculated from these diameter measurements. Resistance to PRR was determined by measuring the TCSA at the beginning of the experiment and 79 weeks after inoculation, and then comparing the growth differences between the inoculated vs. uninoculated trees within a rootstock. As well, the overall growth of the trees was compared. These growth differences were expressed as a percentage. The rootstock were also evaluated by rating the tree foliage on a visual scale of 0 to 5 , where $0=$ healthy and $5=$ completely defoliated, 14 and 55 weeks after inoculation.

Seventy-nine weeks after inoculation, trees on Martin Grande, Thomas, D9, and Barr Duke showed the least difference in TCSA

Table 1. Avocado rootstock selections screened for resistance to Phytophthora cinnmnomi in a field experiment at the South Coast Field Station near Tustin, Calif.

\begin{tabular}{|c|c|c|}
\hline $\begin{array}{l}\text { Rootstock } \\
\text { selection }\end{array}$ & $\begin{array}{l}\text { Horticultural } \\
\text { race }\end{array}$ & $\begin{array}{l}\text { Geographic } \\
\text { origin }\end{array}$ \\
\hline $\begin{array}{l}\text { Martin Grande } \\
\text { (G755a, G755b, G755c) }\end{array}$ & Hybridy & $\begin{array}{l}\text { Coban, Guatemala } \\
\text { Market collection }\end{array}$ \\
\hline Thomas & Mexican & $\begin{array}{l}\text { Escondido, Calif. } \\
\text { Field collection, root rot area }\end{array}$ \\
\hline D9 & Mexican & $\begin{array}{l}\text { Riverside, Calif. } \\
\text { Irradiated Duke budwood }\end{array}$ \\
\hline Barr Duke & Mexican & $\begin{array}{l}\text { Fallbrook, Calif. } \\
\text { Duke } 6 \text { seedling }\end{array}$ \\
\hline Duke 7 & Mexican & $\begin{array}{l}\text { Riverside, Calif. } \\
\text { Duke seedling }\end{array}$ \\
\hline G1033 & Guatemalan & $\begin{array}{l}\text { Hawaii } \\
\text { Hayes seedling }\end{array}$ \\
\hline Toro Canyon & Mexican & $\begin{array}{l}\text { Toro Canyon, Calif. } \\
\text { Field collection, root rot area }\end{array}$ \\
\hline G6 & Mexican & $\begin{array}{l}\text { Acatenango volcano, Guatemala } \\
\text { Field collection }\end{array}$ \\
\hline Borchard & Mexican & $\begin{array}{l}\text { Camarillo, Calif. } \\
\text { Field collection }\end{array}$ \\
\hline Topa Topa & Mexican & $\begin{array}{l}\text { Ojai, Calif. } \\
\text { Seedlings of cultivar Topa Topa }\end{array}$ \\
\hline
\end{tabular}

${ }^{2}$ Tops Topa is a seedling rootstock; the remainder are vegetatively propagated cuttings ${ }^{y}$ Persea americana $\times$ Persea schiedeana hybrid (Ellstrand et al. 1986). 
Table 2. Comparison of percentage growth difference in trunk cross-sectional area (TCSA) relative to uninoculated controls and percentage overall growth in TCSA from the planting date of trees on 12 avocado rootstock, 79 weeks after inoculation with Phytphthora cinnamomi.

\begin{tabular}{|c|c|c|c|}
\hline \multirow[b]{2}{*}{ Rootstock } & \multirow{2}{*}{$\begin{array}{c}\text { Growth difference' } \\
(\%)\end{array}$} & \multicolumn{2}{|c|}{ Overall growth $(\%)$} \\
\hline & & Inoculated & Uninoculated \\
\hline Тора Тора & $86.2 \mathrm{ax}$ & $50 \mathrm{c}$ & $984 \mathrm{~cd}$ \\
\hline G6 & 85.4 a & $122 \mathrm{bc}$ & $1520 \mathrm{ab}$ \\
\hline Borchard & $84.5 \mathrm{a}$ & $41 \mathrm{c}$ & $1100 \mathrm{bc}$ \\
\hline Toro Canyon & $67.0 \mathrm{ab}$ & $254 \mathrm{bc}$ & $878 \mathrm{~cd}$ \\
\hline G1033 & $66.7 \mathrm{ab}$ & $254 \mathrm{bc}$ & $1130 \mathrm{bc}$ \\
\hline Duke 7 & $66.7 \mathrm{ab}$ & $188 \mathrm{bc}$ & $871 \mathrm{~cd}$ \\
\hline Barr Duke & $58.9 \mathrm{bc}$ & $178 \mathrm{bc}$ & $591 \mathrm{~cd}$ \\
\hline D9 & $53.3 \mathrm{bcd}$ & $169 \mathrm{bc}$ & $484 \mathrm{~d}$ \\
\hline Thomas & $50.1 \mathrm{bcd}$ & 873 a & $1710 \mathrm{a}$ \\
\hline G755a ${ }^{w}$ & $47.3 \mathrm{bcd}$ & $231 \mathrm{bc}$ & $585 \mathrm{~cd}$ \\
\hline $\mathrm{G} 755 \mathrm{~b}^{\mathrm{w}}$ & $41.9 \mathrm{~cd}$ & $297 \mathrm{~b}$ & $586 \mathrm{~cd}$ \\
\hline G755c ${ }^{w}$ & $38.0 \mathrm{~d}$ & $315 \mathrm{~b}$ & $645 \mathrm{~cd}$ \\
\hline
\end{tabular}

'Growth difference in TCSA was calculated as: ((uninoculated - inoculated) /uninoculated) x 100. 'Overall growth TCSA was calculated as: ((TCSA at 79 weeks - initial TCSA)/initial TCSA) $\times$

'Means within a column followed by a different letter are significantly different according to Duncan's new multiple range test $(P=0.05)$.

${ }^{\mathrm{w}} \mathrm{G} 755 \mathrm{a}, \mathrm{G} 755 \mathrm{~b}$, and G755c are collectively referred to as Martin Grande.

Table 3. Comparison of visual ratings of 'Hass' avocado trees on 12 rootstock 14 and 55 weeks after inoculation with Phytophthora cinna momi.

\begin{tabular}{lll}
\hline \hline & \multicolumn{2}{c}{ Visual rating $^{2}$} \\
\cline { 2 - 3 } Rootstock & $14 \mathrm{wk}$ & $55 \mathrm{wk}$ \\
\hline Borchard & $3.7 \mathrm{a}^{\mathrm{y}}$ & $4.4 \mathrm{a}$ \\
Topa Topa & $.3 .1 \mathrm{ab}$ & $4.4 \mathrm{a}$ \\
G6 & $0.7 \mathrm{de}$ & $3.7 \mathrm{ab}$ \\
G1033 & $2.2 \mathrm{bc}$ & $2.9 \mathrm{bc}$ \\
D9 & $1.4 \mathrm{~cd}$ & $2.8 \mathrm{bc}$ \\
Toro Canyon & $1.2 \mathrm{cde}$ & $2.6 \mathrm{bcd}$ \\
Duke 7 & $1.1 \mathrm{cde}$ & $2.2 \mathrm{~cd}$ \\
G755c & $0.7 \mathrm{de}$ & $2.2 \mathrm{~cd}$ \\
Barr Duke & $0.1 \mathrm{de}$ & $1.8 \mathrm{cdc}$ \\
G755a & $0.2 \mathrm{de}$ & $1.7 \mathrm{cdc}$ \\
G755b & $1.2 \mathrm{cde}$ & $1.4 \mathrm{de}$ \\
Thomas & $0.0 \mathrm{e}$ & $0.7 \mathrm{e}$ \\
\hline
\end{tabular}

"Visual ratings are on, a scale of 0 to 5 , where 0 $=$ healthy and $5=$ completely defoliated.

${ }^{y}$ Means within a column followed by a different letter are significantly different according to Duncan's new multiple range test $(P=0.05)$.

${ }^{\mathrm{x}} \mathrm{G} 755 \mathrm{a},{ }^{\mathrm{x}} \mathrm{G} 755 \mathrm{~b}_{\mathrm{x}}$ and $\mathrm{G} 755 \mathrm{c}$ are collectively referred to as Martin Grande.

(Table 2). There was no growth difference among trees on the three G755 selections (Table 2). “

Thomas-rooted trees showed by far the greatest overall growth in TCSA of the inoculated trees (Table 2). It was followed by trees on Martin Grande (G755 a, b, and c), G1033, Toro Canyon, Duke 7, Barr Duke, and D9. Trees on G6, Topa Topa, and Borchard showed the least growth in TCSA. Among uninoculated trees, those on Thomas and G6 showed the greatest growth in TCSA, those on D9 the least (Table 2).

At 14 weeks after inoculation, trees on to $P$. cinnamomi than those of Martin Grande or G1033.

In conclusion, trees on Thomas, Martin Grande, Barr Duke, and D9 were the most resistant to PRR. Trees on Topa Topa, Borchard, and G6 were highly susceptible and those on Duke 7, G1033, and Toro Canyon were intermediate in their susceptibility to PRR.

\section{Literature Cited}

Baker, K.F. (cd.). 1972. The U.C. system for producing healthy container-grown plants. Calif. Agr. Expt. Sta. Manual 23. p. 68-86.

Coffey, M.D. 1987. Phytophthora root rot of avocado: an integrated approach to control in California. Plant Dis. 71:1046-1052.

Coffey, M.D. and F. Guillemet. 1987. Profiles of UCR clonal rootstock. Calif. Avocado Sot. Yrbk. 71:169-171.

Coffey, M., F. Guillemet, G. Schieber, and G. Zentmyer. 1988. Persea schiedeana and Martin Grande. Calif. Avocado Sot. Yrbk. 72:107120.

Dolan, T.E. and M.D. Coffey. 1986. Laboratory screening technique for assessing resistance of four avocado rootstock to Phytophthora cinnamomi. Plant Dis. 70:115-118.

Ellstrand, N. C., J.E. Lee, B.O. Bergh, M.D. Coffey, and G.A. Zentmycr. 1986. Isozymes confirm hybrid parentage for ' $\mathrm{G} 755$ ' selections. Calif. Avocado Sot. Yrbk. 70:199-203.

Frolich, E.F. and R.G. Platt. 1971. Use of the etiolation technique in rooting avocado cuttings. Calif. Avocado Sot. Yrbk. 55:97-109.

Gabor, B.K. and M.D. Coffey. 1988. Comparison of resistance to Phytophthora cinnamomi in three avocado rootstock. Phytopathology 78:1546. (Abstr.)

Kellam, M.K. and M.D. Coffey. 1985. Quantitative comparison of the resistance to Phytophthora root rot in three avocado rootstock. Phytopathology 75:230-234.

Kotzé, J.M. and J.M. Darvas. 1983. Integrated control of avocado root rot. Calif. Avocado Sot. Yrbk. 67:83-86.

Pegg, K. G., L.I. Forsberg, and A.W. Whiley. 1982. Avocado root rot. Queensland Agr. J. 108:162-168.

Wachtcll, J.K. 1978. Soil survey of Orange county and the western part of Riverside county, California. U.S. Dept. Agr. Soil Conservation. Serv., Washington, D.C.

Wager, V.A. 1942. Phytophthora cinnamomi and wet soil in relation to the dying back of avocado trees. Hilgardia 14:517-532.

Zentmyer, G.A. 1963. The Duke avocado. Calif. Avocado Sot. Yrbk. 47:28-36.

Zentmyer, G.A. 1978. Origin of root rot resistant rootstock. Cal if. Avocado Sot. Yrbk. 62:8789.

Zentmyer, G.A. 1980. Phytophthora cinnamomi and the diseases it causes. Phytopath. Monogr. 10. Amer. Phytopathol. Soc., St. Paul, Minn.

Zentmyer, G.A., E. Schieber, F.B. Guillemet, and E. Johnson.' 1988. The" origin of the G6 rootstock. Calif. Avocado Sot. Yrbk. 72:243-248. 